INDONESIA ACCOUNTING JOURNAL

VOLUME 2, NUMBER 2, YEAR 2020

${ }^{1}$ Corresponding author

Jurusan Akuntansi

Fakultas Ekonomi dan Bisnis

Universitas Sam Ratulangi

Jl. Kampus UNSRAT

Manado, Indonesia, 95115

E-mail: jroulani@gmail.com

${ }^{2,3}$ Jurusan Akuntansi

Fakultas Ekonomi dan Bisnis

Universitas Sam Ratulangi

Jl. Kampus UNSRAT

Manado, Indonesia, 95115

Article info:

Received 25 January 2020

Accepted 25 January 2020

Available online 27 January 2020

Keywords: taxpayer identification number; tax audit; tax collection; tax revenue

JEL Classification: $\mathrm{H} 24, \mathrm{H} 26$

DOI: http://doi.org/10.3240o/iaj.27712

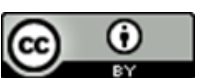

\section{Pengaruh kewajiban kepemilikan NPWP, pemeriksaan pajak, dan penagihan pajak dalam upaya peningkatan penerimaan pajak pada Kantor Pelayanan Pajak Pratama Kotamobagu○}

\author{
Giroth Jessica Roulani ${ }^{1}$ \\ Lintje Kalangi ${ }^{2}$ \\ Sherly Pinatik ${ }^{3}$
}

\begin{abstract}
Taxes are a source of state revenue that is very important because it has a great influence on national development. To achieve the optimal tax revenue, countries need to implement various efforts through tax collection. This research aimed to determine the effect of ownership obligations taxpayer identification number, tax audit and tax collection in an effort to increase tax revenue. The Object of this research were tax officer at Kotamobagu Tax Office. The sampling method was used nonprobability sampling through purposive sampling technique with sample total are 30 person. The data analysis method was used multiple regression analysis. The results showed that the obligation of ownership Taxpayer Identification Number, tax audit and tax collection in partially did not effect in efforts to increase tax revenues, it can be seen from significant value of each variable is greater than 0,05.
\end{abstract}

\section{Pendahuluan}

Pajak merupakan salah satu aspek yang terpenting dalam proses pembangunan suatu negara, terlebih bagi negara-negara yang sedang berkembang seperti Indonesia. Pajak adalah iuran yang diberikan rakyat kepada negara dan merupakan penerimaan bagi pemerintah yang diolah guna untuk membiayai keperluan negara. Untuk mendongkrak peningkatan penerimaan Negara melalui sektor pajak, dibutuhkan partisipasi aktif dari seluruh wajib pajak untuk memenuhi segala kewajiban perpajakannya dengan baik dan juga peran pemerintah yang harus mengambil langkahlangkah kebijakan ataupun upaya agar dapat menambah kesadaran masyarakat agar mau membayar pajak (Polii dan Sondakh, 2017:2).

Pada tahun 2008 pemerintah melalui Direktorat Jenderal Pajak mengeluarkan kebijakan berupa sunset policy. Kebijakan sunset policy ini diharapkan dapat meningkatkan partisipasi dan kesadaran masyarakat dalam membayar pajak sehingga dana pajak yang dirasakan dapat lebih luas bagi kemakmuran dan kesejahteraan masyarakat. Pemberian NPWP kepada setiap wajib pajak disertai dengan pelaksanaan hak dan kewajiban perpajakan. Wajib pajak adalah orang pribadi atau badan, meliputi pembayar pajak, pemotong pajak dan pemungut pajak, yang mempunyai hak dan kewajiban perpajakan sesuai dengan ketentuan perundang-undangan perpajakan (Resmi, 2017:21). Pengesahan pemberian NPWP dilakukan dengan pemberian Surat Keterangan Terdaftar. Semakin banyak yang diisi kewajiban perpajakan oleh wajib pajak secara benar dan tepat, maka penerimaan pajak akan meningkat (Setiawan, 2007;59). 
Selain mewajibkan masyarakat wajib pajak memiliki NPWP, pemerintah juga perlu meningkatkan penegakkan hukum lain. Penegakkan hukum ini salah satunya pemeriksaan pajak. Tujuan pemeriksaan adalah untuk menguji kepatuhan pemenuhan kewajiban perpajakan dan untuk tujuan lain (pajak.go.id 03/07/2016). Dengan dilakukannya pemeriksaan pajak terhadap wajib pajak, akan memberikan pengaruh yang positif terhadap peningkatan penerimaan pajak (Simanungkalit et al., 2015:2). Adapun pemeriksaan pajak ini dilakukan oleh Direktorat Jenderal Pajak melalui unit pelaksana yaitu fungsional pemeriksa pajak baik yang berada di kantor pelayanan, kantor wilayah, maupun kantor pusat.

Selain pemeriksaan pajak, ada juga kebijakan yang dilakukan dalam usaha untuk mengoptimalkan penerimaan pajak yaitu dengan melakukan penagihan pajak. Penagihan pajak dilakukan karena masih banyak wajib pajak terdaftar yang tidak melunasi hutang pajaknya sehingga perlu tindakan penagihan yang mempunyai kekuatan hukum yang bersifat mengikat dan memaksa. Menurut Undang-Undang Nomor 19 tahun 2000 yang dimaksud dengan penagihan pajak adalah serangkaian tindakan agar penanggung pajak melunasi utang pajak dan biaya penagihan pajak dengan menegur atau memperingatkan, melaksanakan penagihan seketika dan sekaligus memberitahukan surat paksa, mengusulkan pencegahan, melaksanakan penyitaan, melaksanakan penyanderaan dan menjual barang yang telah disita.

Oleh karena itu dengan dikeluarkannya undang-undang tentang penagihan pajak tersebut diharapkan kegiatan penagihan pajak dapat dilaksanakan sebagaimana mestinya karena telah terlihat jelas bahwa tujuan dibuatnya undang-undang tersebut adalah sebagai landasan hukum bagi fiskus untuk melakukan penagihan kepada wajib pajak yang mempunyai tunggakan pajak sehingga wajib pajak pun termotivasi untuk membayar yang selanjutnya diharapkan dapat meningkatkan penerimaan pajak.

\section{Tinjauan pustaka}

Pengertian pajak. Menurut UndangUndang Ketentuan Umum dan Tata Cara Perpajakan Nomor 28 tahun 2007 Pasal 1 ayat 1 , pajak adalah kontribusi wajib kepada negara yang terutang oleh orang pribadi atau badan yang bersifat memaksa berdasarkan undang-undang, tidak mendapatkan imbalan secara langsung dan digunakan untuk keperluan negara bagi sebesar-besarnya kemakmuran rakyat.

Nomor Pokok Wajib Pajak. Nomor Pokok Wajib Pajak (NPWP) adalah nomor yang diberikan kepada wajib pajak sebagai sarana dalam administrasi perpajakan yang dipergunakan sebagai tanda pengenal diri atau identitas wajib pajak dalam melaksanakan hak dan kewajibannya (pajak.go.id, 03/07/2016).

Pemeriksaan pajak. Pemeriksaan pajak adalah serangkaian kegiatan menghimpun dan mengolah data, keterangan dan/atau bukti yang dilaksanakan secara objektif dan profesional berdasarkan suatu standar pemeriksaan untuk menguji kepatuhan pemenuhan kewajiban perpajakan dan/atau untuk tujuan lain dalam rangka melaksanakan ketentuan peraturan perundang-undangan perpajakan (Ilyas dan Wicaksono, 2015:32).

Penagihan pajak. Dalam UndangUndang Nomor 19 Tahun 2000 pasal 1 butir 9 penagihan pajak adalah serangkaian tindakan agar penanggung pajak melunasi utang pajak dan biaya penagihan pajak dengan menegur atau memperingatkan, melaksanakan penagihan seketika dan sekaligus memberitahukan surat paksa, mengusulkan pencegahan, melaksankaan penyitaan, melaksanakan penyanderaan, menjual barang yang telah disita.

Upaya peningkatan penerimaan pajak. Upaya peningkatan penerimaan pajak merupakan usaha yang dilakukan untuk memaksimalkan penerimaan negara pada sektor perpajakan dengan diterbitkannya kebijakan-kebijakan pajak dari pemerintah yang harus dipatuhi oleh wajib pajak.

Penelitian terdahulu. Jannata et al. (2019) menunjukkan bahwa terdapat 
pengaruh antara kewajiban kepemilikan NPWP dan pemeriksaan pajak terhadap ukuran penerimaan pajak. Mohammad et al. (2017) menunjukkan bahwa pemeriksaan pajak dan penagihan pajak berpengaruh secara parsial terhadap penerimaan pajak. Harelimana (2018) membuktikan bahwa pemeriksaan pajak berpengaruh terhadap penerimaan pajak. Olatunji dan Oludayo (2018) menunjukkan bahwa variabel kepemilikan NPWP berpengaruh secara signifikan dalam meningkatkan penerimaan pajak sehingga menghasilkan pendapatan secara internal. Muhammad dan Sunarto (2015) menunjukkan bahwa secara parsial pemeriksaan pajak, penagihan pajak tidak berpengaruh positif terhadap penerimaan pajak. Berdasarkan hasil-hasil kajian penelitian terdahulu, maka hipotesis dalam penelitian ini adalah Kewajiban kepemilikan NPWP (X1), pemeriksaan pajak (X2) dan penagihan pajak (X3) berpengaruh signifikan dalam upaya peningkatan penerimaan pajak $(\mathrm{Y})$.

\section{Metode penelitian}

Jenis penelitian yang digunakan dalam penelitian ini adalah penelitian kuantitatif. Tempat penelitian ini dilakukan pada Kantor Pelayanan Pajak (KPP) Pratama Kotamobagu. Jangka waktu penyusunan penelitian ini mulai dari Maret 2019 sampai dengan selesai. Sampel yang diambil berjumlah 30 orang pegawai yang terbagi pada bidang pelayanan pajak, bagian pemeriksa pajak dan bagian penagih pajak serta pegawai internal lainnya dari jumlah keseluruhan 84 pegawai dikarenakan pada saat dilakukan sebab saat kuesioner disebarkan terdapat beberapa pegawai di Kantor Pelayanan Pajak Pratama Kotamobagu sedang tidak berada di tempat.

Jenis data yang digunakan dalam penelitian ini adalah data kuantitatif. Data kuantitatif bisa disebut sebagai data berupa angka dan berbagai operasi matematika bisa dilakukan pada data kuantitatif (Santoso, 2019:8). Metode pengumpulan data yang digunakan dalam penelitian ini, yaitu dengan cara memberi seperangkat pertanyaan atau pernyataan tertulis dalam hal ini kuesioner kepada responden untuk dijawab. Penelitian ini menggunakan metode analisis regresi linear berganda yang adalah hubungan secara linear antara dua atau lebih variabel independen dengan variabel dependen, maka akan digunakan model analisa regresi linear berganda adalah sebagai berikut.

$$
\mathrm{Y}=\alpha+\beta \mathrm{X} 1+\beta \mathrm{X} 2+\beta \mathrm{X} 3
$$

Dimana $X$ adalah kewajiban kepemilikan NPWP, pemeriksaan pajak dan penagihan pajak, sedangkan $\mathrm{Y}$ adalah upaya peningkatan penerimaan pajak. Uji koefisien determinasi $\left(\mathrm{R}^{2}\right)$ untuk mengetahui persentase kontribusi pengaruh variabel independen (kewajiban kepemilikan NPWP, pemeriksaan pajak dan penagihan pajak) atas variabel dependen (upaya peningkatan penerimaan pajak). Uji kualitas data digunakan dalam penelitian ini dengan menguji validitas instrumen untuk mengukur valid tidaknya suatu kuesioner dan uji reliabilitas instrumen untuk menguji apakah suatu pertanyaan/pernyataan dikatakan reliabel atau handal jika jawaban seseorang terhadap pertanyaan adalah konsisten atau stabil dari waktu ke waktu. Uji asumsi klasik dengan menggunakan uji normalitas untuk menguji apakah dalam sebuah model regresi variabel dependen dan variabel independen atau keduanya mempunyai distribusi data normal atau tidak. Model regresi yang baik adalah distribusi data normal atau mendekati normal. Uji hipotesis digunakan untuk menguji pengaruh variabel bebas secara parsial, jika $\mathrm{t}$ hitung $>\mathrm{t}$ tabel maka $\mathrm{H}_{\mathrm{O}}$ ditolak berarti $\mathrm{H}_{\mathrm{a}}$ diterima.

Definisi operasional dan pengukuran variabel dari penelitian ini adalah:

1. Kewajiban Kepemilikan NPWP (X1), Pemeriksaan Pajak (X2), Penagihan Pajak (X3). Variabel ini diukur dengan skala Likert 1 sampai 5 (Sangat Tidak Setuju, Tidak Setuju, Kurang Setuju, Setuju hingga Sangat Setuju).

2. Upaya Peningkatan Penerimaan Pajak (Y). Variabel ini diukur dengan skala Likert 1 sampai 5 (Sangat Tidak Setuju, Tidak Setuju, Kurang Setuju hingga Sangat Setuju). 


\section{Hasil penelitian dan pembahasan \\ Hasil penelitian}

Tabel 1 menunjukkan bahwa atas 30 responden, variabel independen kewajiban kepemilikan NPWP memiliki nilai minimum sebesar 19 dan maksimum sebesar 24 dengan rata-rata total jawaban 21.70 serta standar deviasi 1.784. Variabel pemeriksaan pajak memiliki nilai minimum sebesar 20 dan maksimum sebesar 25 dengan rata-rata total jawaban 22.87 serta standar deviasi 1.943. Variabel penagihan pajak memiliki nilai minimum sebesar 18 dan maksimum sebesar 25 dengan rata-rata total jawaban 21.97 serta standar deviasi 2.042. Sedangkan pada variabel dependen yaitu upaya peningkatan penerimaan pajak memiliki nilai minimum sebesar 19 dan maksimum sebesar 25 dengan rata-rata total jawaban 22.47 serta standar deviasi 2.013.

Tabel 1. Hasil uji statistik deskriptif

\begin{tabular}{cccccc}
\hline & N & Min & Max & Mean & $\begin{array}{c}\text { Std. } \\
\text { Dev. }\end{array}$ \\
\hline X1 & 30 & 19 & 25 & 21.70 & 1.784 \\
X2 & 30 & 20 & 25 & 22.87 & 1.943 \\
X3 & 30 & 18 & 25 & 21.97 & 2.042 \\
Y & 30 & 19 & 25 & 22.47 & 2.013 \\
\hline \multicolumn{4}{l}{ Sumber: Data primer yang diolah, 2019 }
\end{tabular}

Tabel 2 menunjukkan bahwa semua butir pernyataan untuk variabel yang memiliki subvariabel kewajiban kepemilikan NPWP (X1) berada pada tingkat signifikan yaitu 0,05 , maka dapat disimpulkan bahwa pernyataan penelitian valid.

Tabel 2. Hasil uji validitas kewajiban kepemilikan NPWP

\begin{tabular}{cccc}
\hline Pernyataan & $\begin{array}{c}\text { Pearson } \\
\text { Correlation }\end{array}$ & Sig. & Keterangan \\
\hline X1.1 & 0.872 & 0.000 & Valid \\
X1.2 & 0.839 & 0.000 & Valid \\
X1.3 & 0.839 & 0.000 & Valid \\
X1.4 & 0.815 & 0.000 & Valid \\
X1.5 & 0.853 & 0.000 & Valid \\
\hline Sumber: Data primer yang diolah, 2019 &
\end{tabular}

Tabel 3 menunjukkan bahwa semua butir pernyataan untuk variabel yang memiliki subvariabel pemeriksaan pajak (X2) berada pada tingkat signifikan yaitu dibawah 0,05, maka dapat disimpulkan bahwa pernyataan penelitian valid.

Tabel 3. Hasil uji validitas pemeriksaan pajak

\begin{tabular}{cccc}
\hline Pernyataan & $\begin{array}{c}\text { Pearson } \\
\text { Correlation }\end{array}$ & Sig. & Keterangan \\
\hline X2.1 & 0.900 & 0.000 & Valid \\
X2.2 & 0.865 & 0.000 & Valid \\
X2.3 & 0.825 & 0.000 & Valid \\
X2.4 & 0.899 & 0.000 & Valid \\
X2.5 & 0.809 & 0.000 & Valid \\
\hline
\end{tabular}

Sumber : Data primer yang diolah, 2019

Tabel 4 menunjukkan bahwa semua butir pernyataan untuk variabel yang memiliki subvariabel penagihan pajak (X3) berada pada tingkat signifikan yaitu dibawah 0,05, maka dapat disimpulkan bahwa pernyataan penelitian valid.

Tabel 4. Hasil uji validitas penagihan pajak

\begin{tabular}{cccc}
\hline Pernyataan & $\begin{array}{c}\text { Pearson } \\
\text { Correlation }\end{array}$ & Sig. & Keterangan \\
\hline X3.1 & 0.818 & 0.000 & Valid \\
X3.2 & 0.848 & 0.000 & Valid \\
X3.3 & 0.761 & 0.000 & Valid \\
X3.4 & 0.854 & 0.000 & Valid \\
X3.5 & 0.772 & 0.000 & Valid \\
\hline
\end{tabular}

Sumber: Data primer yang diolah, 2019

Tabel 5 menunjukkan bahwa semua butir pernyataan untuk variabel yang memiliki subvariabel upaya peningkatan penerimaan pajak (Y) berada pada tingkat signifikan yaitu dibawah 0,05, maka dapat disimpulkan bahwa pernyataan penelitian valid.

Tabel 5. Hasil uji validitas upaya peningkatan penerimaan pajak

\begin{tabular}{cccc}
\hline Pernyataan & $\begin{array}{c}\text { Pearson } \\
\text { Correlation }\end{array}$ & Sig. & Keterangan \\
\hline Y.1 & 0.843 & 0.000 & Valid \\
Y.2 & 0.863 & 0.000 & Valid \\
Y.3 & 0.830 & 0.000 & Valid \\
Y.4 & 0.876 & 0.000 & Valid \\
Y.5 & 0.604 & 0.000 & Valid \\
\hline \multicolumn{4}{l}{ Sumber : Data primer yang diolah, 2019 }
\end{tabular}

Tabel 6 menunjukkan bahwa pernyataan dalam kuesioner ini reliabel karena mempunyai nilai Conbranch's Alpha lebih besar dari 0,70. Hal ini menunjukkan bahwa setiap item pernyataan yang digunakan akan mampu memperoleh data konsisten yang 
berarti bila pernyataan itu diajukan kembali akan diperoleh jawaban yang relatif sama dengan jawaban sebelumnya.

Tabel 6. Uji reliabilitas instrumen

\begin{tabular}{cccc}
\hline Variabel & $\begin{array}{c}\text { Cronbach's } \\
\text { Alpha }\end{array}$ & $\begin{array}{c}\text { N of } \\
\text { Item }\end{array}$ & Keterangan \\
\hline X1 & 0,898 & 5 & Reliabel \\
X2 & 0,909 & 5 & Reliabel \\
X3 & 0,869 & 5 & Reliabel \\
Y & 0,867 & 5 & Reliabel \\
\hline
\end{tabular}

Sumber: Data primer yang diolah, 2019

Tabel 7 menunjukkan bahwa hasil uji normalitas dengan menggunakan Kolmogorov-Smirnov Test menunjukkan variabel dependen dan variabel independen mempunyai nilai signifikan 0.171 yang mana menunjukkan tingkat signifikan lebih dari 0,05 sehingga hal ini berarti bahwa uji test normalitas pada penelitian ini adalah terdistrbusi dengan normal.

Tabel 7. Hasil uji normalitas

\begin{tabular}{llr}
\hline & & $\begin{array}{c}\text { Unstandardized } \\
\text { Residual }\end{array}$ \\
\hline $\mathrm{N}$ & Mean & 30 \\
Normal & 0.0000000 \\
Parameters ${ }^{\text {,b }}$ & Std. & 3.57037365 \\
& Deviation & \\
Most & Absolute & 0.135 \\
Extreme & Positive & 0.072 \\
Differences & Negative & -0.135 \\
Test Statistic & 0.135 \\
Asymp. Sig. (2-tailed) & $0.171^{\mathrm{c}}$ \\
\hline a. Test distribution is Normal. & \\
b. Calculated from data. & \\
c. Lilliefors Significance Correction. \\
Sumber: Data primer yang diolah, 2019
\end{tabular}

Tabel 8 menunjukkan bahwa nilai konstanta sebesar 4.808 artinya kewajiban kepemilikan NPWP (X1), pemeriksaan pajak (X2) dan penagihan pajak (X3) dianggap konstan maka upaya peningkatan penerimaan pajak konstan sebesar sebesar 4.808. Koefisien regresi variabel kewajiban kepemilikan NPWP (X1) sebesar 0,215 artinya kewajiban kepemilikan NPWP mengalami kenaikan 1\%, maka upaya peningkatan penerimaan pajak (Y) akan mengalami peningkatan sebesar 0,215 dengan asumsi variabel independen lain nilainya tetap. Koefisien regresi variabel pemeriksaan pajak (X2) sebesar 0,380 artinya pemeriksaan pajak mengalami kenaikan $1 \%$, maka upaya peningkatan penerimaan pajak (Y) akan mengalami peningkatan sebesar 0,380 dengan asumsi variable independen lain nilainya tetap. Koefisien regresi variabel penagihan pajak (X3) sebesar 0,196 artinya penagihan pajak mengalami kenaikan $1 \%$, maka upaya peningkatan penerimaan pajak (Y) akan mengalami peningkatan sebesar 0,196 dengan asumsi variabel independen lain nilainya tetap.

Tabel 8. Hasil uji regresi linear berganda

\begin{tabular}{|c|c|c|c|c|c|}
\hline Models & $\begin{array}{c}\begin{array}{c}\text { Unst. } \\
\text { Coef. }\end{array} \\
\text { B }\end{array}$ & $\begin{array}{c}\begin{array}{c}\text { St. } \\
\text { Coef. }\end{array} \\
\text { Std. } \\
\text { Error }\end{array}$ & $\begin{array}{l}\text { Unst. } \\
\text { Coef. } \\
\text { Beta }\end{array}$ & $t$ & Sig. \\
\hline Constant & 4.808 & 4.866 & & 0.988 & 0.332 \\
\hline X1 & 0.215 & 0.208 & 0.190 & 1.032 & 0.312 \\
\hline $\mathrm{X} 2$ & 0.380 & 0.189 & 0.367 & 2.012 & 0.055 \\
\hline X3 & 0.196 & 0.205 & 0.199 & 0.959 & 0.347 \\
\hline
\end{tabular}

Tabel 9 menunjukkan bahwa nilai Adjusted $\mathrm{R}^{2}$ sebesar 0.280 dalam arti kontribusi pengaruh variabel independen (kewajiban kepemilikan NPWP, pemeriksaan pajak, dan penagihan pajak) terhadap variabel dependen (upaya peningkatan penerimaan pajak) sebesar $28 \%$ sedangkan sisanya sebesar $72 \%$ dipengaruhi atau dijelaskan oleh variabel lain yang tidak dimasukkan dalam penelitian ini, seperti variabel kesadaran masyarakat dan kepatuhan wajib pajak seperti dalam penelitian Suryadi (2006), atau inflasi.

Tabel 9. Hasil uji koefisien determinasi $\left(\mathbf{R}^{2}\right)$

\begin{tabular}{ccccc}
\hline Model & $\mathbf{R}$ & $\mathbf{R}^{2}$ & Adj. $\mathbf{R}^{2}$ & $\begin{array}{c}\text { Std. } \\
\text { Error of } \\
\text { the } \\
\text { Estimate }\end{array}$ \\
\hline 1 & $0.596^{\mathrm{a}}$ & 0.355 & 0.280 & 1.707 \\
\hline Sumber: Data primer yang diolah, 2019 & &
\end{tabular}

\section{Pembahasan}

Berdasarkan Tabel 8 dapat diketahui nilai t hitung untuk masing-masing variabel bebas. Untuk variabel bebas kewajiban kepemilikan NPWP diperoleh $t$ hitung sebesar 1,032 yakni lebih kecil dari t tabel sebesar 2,045. Dengan demikian berarti bahwa secara individual kewajiban 
kepemilikan NPWP tidak berpengaruh dalam upaya peningkatan penerimaan pajak sehingga dapat disimpulkan Ha1 ditolak. Untuk variabel bebas kedua yaitu pemeriksaan pajak diperoleh nilai $\mathrm{t}$ hitung sebesar 2,012 yakni lebih kecil dari t tabel sebesar 2,045, hal ini berarti bahwa secara parsial pemeriksaan pajak tidak berpengaruh dalam upaya peningkatan penerimaan pajak sehingga dapat disimpulkan bahwa $\mathrm{Ha} 2$ ditolak. Untuk variabel bebas ketiga yaitu penagihan pajak diperoleh $t$ hitung sebesar 0,959 yakni lebih kecil dari t tabel sebesar 2,045, hal ini berarti bahwa secara individual penagihan pajak tidak berpengaruh dalam upaya peningkatan penerimaan pajak sehingga dapat disimpulkan bahwa Ha3 ditolak.

Pengaruh kewajiban kepemilikan NPWP dalam upaya peningkatan penerimaan pajak. Hasil uji hipotesis 1 yang ditunjukkan pada Tabel 8 , nilai $t$ hitung pada variabel kewajiban kepemilikan NPWP (X1) adalah 1,032 karena nilai $t$ hitung sebesar 1,032 lebih besar dari t table sebesar 2,045 sehingga $\mathrm{H} 0$ diterima dan $\mathrm{Ha}$ ditolak, sehingga dapat dikatakan bahwa kewajiban kepemilikan NPWP tidak berpengaruh dalam upaya peningkatan penerimaaan pajak. Meskipun banyak wajib pajak yang memiliki NPWP maka hal itu belum tentu akan meningkatkan penerimaan pajak. Sesuai dengan fungsinya NPWP merupakan suatu sarana administrasi perpajakan yang dipergunakan sebagai tanda pengenal diri atau identitas wajib pajak. NPWP juga dipergunakan untuk menjaga ketertiban dalam membayar pajak dan pengawasan administrasi perpajakan. Walaupun begitu wajib pajak yang telah memiliki NPWP belum tentu diharuskan membayar pajak terutangnya.

Pengaruh pemeriksaan pajak dalam upaya peningkatan penerimaan pajak. Hasil uji hipotesis 2 yang ditunjukkan pada Tabel 8 diperoleh nilai $t$ hitung sebesar 2,012 yakni lebih besar dari t table sebesar 2,045. Hal ini berarti bahwa secara parsial pemeriksaan pajak tidak terdapat pengaruh dalam upaya peningkatan penerimaan pajak sehingga dapat disimpulkan bahwa $\mathrm{Ha} 2$ ditolak. Sesungguhnya pemeriksaan pajak bertujuan untuk meredam kecurangan-kecurangan yang dilakukan oleh wajib pajak untuk meminimalkan pajaknya. Dalam rangka pemenuhan hak dan kewajiban perpajakan wajib pajak, maka pegawai perpajakan melakukan pemeriksaan rutin terhadap wajib pajak. Apabila telah dilakukan pemeriksaan dengan baik maka akan berdampak pada peningkatan penerimaan pajak negara.

Pengaruh penagihan pajak dalam upaya peningkatan penerimaan pajak. Hasil uji hipotesis 3 yang ditunjukkan pada Tabel 8 adalah nilai $t$ hitung pada variabel penagihan pajak (X3) adalah 0,347. Karena nilai t hitung sebesar 0,347 besar dari t tabel sebesar 1,691. Maka H0 diterima dan Ha ditolak, sehingga dapat dikatakan bahwa variabel penagihan pajak tidak terdapat pengaruh dalam upaya peningkatan penerimaan pajak, walaupun penagihan pajak itu sering dilakukan belum bisa disimpulkan bahwa penerimaan pajak semakin meningkat. Dengan adanya penagihan pajak, wajib pajak yang tidak mau membayar pajaknya dapat dipaksa untuk memenuhi kewajibannya dalam membayar pajak, sehingga dapat meningkatkan penerimaan pajak. Namun, berdasarkan hasil uji hipotesis dapat dilihat bahwa Wajib pajak dalam melaksanakan kewajiban perpajakannya setelah dilakukan penagihan pajak dengan surat paksa masih kurang memiliki rasa tanggung jawab terhadap kewajibannya. Hal ini dapat disebabkan oleh beberapa kemungkinan seperti wajib pajak enggan membayar pajak dikarenakan kondisi keuangan yang tidak mendukung, kurangnya pemahaman (perubahan UU perpajakan), dan kurangnya kesadaran wajib pajak dalam hal membayar pajak.

\section{Kesimpulan dan saran Kesimpulan}

Penelitian ini bertujuan untuk menguji pengaruh kewajiban kepemilikan NPWP, pemeriksaan pajak dan penagihan pajak dalam upaya peningkatan penerimaan pajak. Responden penelitian ini berjumlah 30 
orang pegawai pajak (fiskus) pada Kantor Pelayanan Pajak (KPP) Pratama Kotamobagu. Berdasarkan pada data yang telah dikumpulkan dan pengujian yang telah dilakukan terhadap permasalahan dengan menggunakan model regresi berganda, maka dapat disimpulkan bahwa:

1. Variabel kewajiban kepemilikan NPWP tidak berpengaruh secara parisal dalam upaya peningkatan penerimaan pajak di KPP Pratama Kotamobagu. Hal ini ditunjukkan nilai t hitung lebih kecil dari $\mathrm{t}$ tabel $(1,032<2,045)$, dan nilai signifikansi yang lebih besar dari nilai signifikansi $5 \%(0,312>0,05)$.

2. Variabel pemeriksaan pajak tidak berpengaruh secara parsial dalam upaya peningkatan penerimaan pajak di KPP Pratama Kotamobagu. Hal ini ditunjukkan nilai thitung lebih kecil dari $\mathrm{t}$ tabel $(2,012<2,045)$, dan nilai signifikansi yang lebih besar dari nilai signifikansi 5\% $(0,055>0,05)$.

3. Variabel penagihan pajak tidak berpengaruh dalam upaya peningkatan penerimaan pajak di KPP Pratama Kotamobagu. Hal ini ditunjukkan nilai thitung lebih kecil dari $t$ tabel $(0,959<2,045)$, dan nilai signifikansi yang lebih besar dari nilai signifikansi 5\% $(0,347>0,05)$. Sesuai dengan hasil penelitian, ketiga variabel menyatakan tidak berpengaruh dalam upaya peningkatan penerimaaan pajak di Kantor Pelayanan Pajak Pratama Kotamobagu.

\section{Saran}

Saran atas penelitian ini adalah:

1. Petugas pajak perlu memperhatikan kinerja dan mengedepankan fungsi pembinaan atau mengadakan berbagai sosialisasi mengenai pajak agar wajib pajak dengan sukarela memenuhi kewajiban perpajakannya.

2. Penelitian selanjutnya diharapkan memperluas objek penelitian di seluruh wilayah Kantor Pelayanan Pajak Kabupaten/Kota Provinsi Sulawesi Utara.

3. Dalam penelitian ini jumlah sampel yang digunakan relatif kecil, sehingga diharapkan untuk penelitian selanjutnya dapat menggunakan sampel yang lebih banyak. Disarankan juga agar menambahkan variabel lain yang tidak ada dalam penelitian ini, sehingga dapat ditemukan variabel baru yang mempengaruhi upaya peningkatan penerimaan pajak.

\section{Daftar pustaka}

Harelimana, J. B. (2018). Effect of tax audit on revenue collection in Rwanda. Global Journal of Management and Business Research Accounting and Auditing, 18(2), 1-11. https://globaljournals.org/GJMBR_Volume18/ 1-Effect-of-Tax-Audit-on-Revenue.pdf.

https://www.pajak.go.id/id/pemeriksaan. Di akses Juli, 3, 2016.

https://www.pajak.go.id/id/wajib-pajak-dan-npwp. Di akses Juli, 3, 2016.

Ilyas, W. B. \& Wicaksono P. (2015). Pemeriksaan pajak. Jakarta: Mitra Wacana Media.

Jannata, R. A., Nurhayati, N., \& Halimatusadiah, E. (2019). Pengaruh kepemilikan NPWP dan pemeriksaan pajak terhadap ukuran penerimaan pajak penghasilan badan. Jurnal Unisba: Kajian Akuntansi, 20(1), 58-64. https://ejournal.unisba.ac.id/index.php/kajian_a kuntansi/article/view/4502/pdf.

Mohammad, I., Saerang, D. P. E., \& Pangerapan, S. (2017). Pengaruh pemeriksaan pajak dan penagihan pajak terhadap penerimaan pajak pada Kantor Pelayanan Pajak Pratama Manado. Going Concern: Jurnal Riset Akuntansi, 12(2), 938-949. https://doi.org/10.32400/gc.12.2.18370.2017.

Muhammad, A., \& Sunarto. (2018). Pengaruh pemeriksaan pajak, penagihan pajak dan kepatuhan wajib pajak terhadap penerimaan pajak studi kasus pada KPP Pratama Raba Bima Tahun 20122015. Jurnal Akuntansi Dewantara, 2(1), 37-45. http://jurnal.ustjogja.ac.id/index.php/akuntansi dewantara/article/view/2220/pdf.

Olatunji, C., O. \& Oludayo, A. J. (2018). Impact of taxpayer identification number on revenue generation in Ekiti State. Europian Journal of Accounting, Auditing and Finance Research, 6(5), 35-46. http://www.eajournals.org/wpcontent/uploads/Impact-of-TaxpayerIdentification-Number-on-Revenue-Generationin-Ekiti-State.pdf.

Polii, C. M., \& Sondakh, J. J. (2017). Pengaruh modernisasi administrasi perpajakan terhadap kinerja Kantor Pelayanan Pajak Pratama Kotamobagu. Jurnal EMBA 5(2), 1965-1975. https://doi.org/10.35794/emba.v5i2.16477.

Resmi, S. (2017) Perpajakan: Teori dan Kasus, Edisi 10. Jakarta: Salemba Empat.

Setiawan, D. A. (2007). Analisis hubungan antara ekstensifikasi wajib pajak dan surat setoran pajak dengan penerimaan pajak (Studi kasus pada KPP Jakarta Palmerah). Media Riset Akuntansi, Auditing dan Informasi, 7(1), 57-82. http://dx.doi.org/10.25105/mraai.v7i1.971. 
Santoso, S. (2019). Menguasai SPSS Versi 25. Jakarta: PT. Elex Media Komputindo.

Simanungkalit, A., Poputra, A. T., \& Runtu, T. (2015). Pengaruh kewajiban kepemilikan NPWP, pemeriksaan pajak dan penagihan pajak terhadap penerimaan pajak (Studi kasus pada KPP Pratama Bitung). Goning Concern: Jurnal Riset Akuntansi, 10(4), 1-10. https://doi.org/10.32400/gc.10.4.10514.2015.

Suryadi. (2006). Model hubungan kausal kesadaran, pelayanan, kepatuhan wajib pajak dan pengaruhnya terhadap kinerja penerimaan pajak. Jurnal Keuangan Publik, 4(1), 105-121. https://adoc.tips/jurnal-keuangan-publik-vol-4no-1-april-2006-hal.html.

Undang-Undang Republik Indonesia Nomor 19 Tahun 2000 tentang Perubahan atas Undang-undang Nomor 19 Tahun 1997 tentang Penagihan Pajak dengan Surat Paksa.

Undang-Undang Republik Indonesia Nomor 28 Tahun 2007 tentang Ketentuan Umum dan Tata Cara Perpajakan. 